\title{
Tissue-Resident Memory T cells in Cytomegalovirus Infection
}

Jenny Tosca Thom ${ }^{\mathrm{a}}$ and Annette Oxenius ${ }^{\text {a† }}$

\begin{abstract}
Herpesviruses establish life-long infection in their hosts and maintain latent reservoirs for sporadic reactivation at peripheral sites, such as skin and mucosae. For herpes simplex virus infection, experimental studies in mice revealed that immediate protection against local reactivation or superinfection events in the skin relies on tissue resident memory $T$ cells $\left(T_{R M}\right)$ rather than on their circulating counterparts. Recent evidence extends this notion to cytomegalovirus infection, which that potently induces $\mathrm{T}_{\mathrm{RM}}$ cells in both mice and humans particularly in mucosal tissues that constitute important viral sanctuaries and are relevant entry sites for challenge and superinfections. The discovery unravels promising opportunities to exploit cytomegalovirus based vaccine vectors for the specific induction of tissue resident $T$ cell subsets.
\end{abstract}




\section{Introduction}

Herpesviruses share the extraordinary capacity to evade immunity, persist in tissues, and establish latent reservoirs, which allow for viral reactivation and transmission. Cytomegaloviruses (CMVs) are beta-herpesviruses that establish life-long latency in many organs including mucosal tissues. $60-90 \%$ of the world population is infected with human CMV (HCMV). While acute HCMV infection is largely asymptomatic in immunocompetent individuals, it is a frequent cause of morbidity and mortality among the immunocompromised, including AIDS patients, transplant recipients, and congenitally or perinatally infected infants. Although CMVs have co-evolved with their mammalian hosts and therefore exhibit strict species specificity, experimental infection of mice with murine CMV (MCMV) is considered a relevant model for human CMV infection in particular with respect to the functional and phenotypic characteristics of the elicited T cell responses. In both mice and humans CMV infection elicits substantial and sustained expansions of specific CD8 ${ }^{+} \mathrm{T}$ cells, a process known as memory "inflation" (reviewed in [1]). The MCMV model has been particularly useful in dissecting, on a mechanistic level, the parameters driving this atypical $\mathrm{CD}^{+} \mathrm{T}$ cell response. Furthermore, experimental MCMV infection has revealed that $T$ cells are the principal effectors of the adaptive immune response. MCMV replication as well as $\mathrm{T}$ cell-mediated control follow tissue-specific patterns: while lytic MCMV replication is controlled within the first weeks of primary infection in visceral organs by IFNy-producing $\mathrm{CD}^{+} \mathrm{T}$ cells, MCMV persists for months in mucosal sites fostering its transmission via mucosal secretions and specifically in the salivary glands (SG), virus replication is exclusively under the control of $\mathrm{CD} 4^{+}$and not $\mathrm{CD}^{+} \mathrm{T}$ cells $[2,3]$. The saliva is the most relevant vehicle for horizontal transmission of both HCMV and MCMV and the capacity of the virus to actively replicate in the SG for prolonged time periods supports its transmission efficiency. To achieve this, CMV 
has evolved to encode a number of immune evasion genes that interfere with MHC I restricted antigen presentation. Particularly in the SG, the action of MCMV-encoded immune evasion genes completely deprives $\mathrm{CD} 8^{+} \mathrm{T}$ cells of their cognate antigen by exceptionally efficient MHC I downregulation in infected acinar glandular epithelial cells, the saliva producing cell type of the SG [4]. In consequence, the SG is the only organ where MCMV resists $\mathrm{CD} 8^{+} \mathrm{T}$ cell mediated control. This knowledge is based on studies conducted during primary MCMV infection and suggests that $\mathrm{CD} 8^{+} \mathrm{T}$ cells may also be incapable of curtailing viral reactivation or superinfection events during latency. However, the validity of this theory has never been tested and has in fact been called into question with the discovery of the SG's enormous potential to accommodate MCMV-specific tissue-resident memory $\mathrm{CD}^{+} \mathrm{T}\left(\mathrm{T}_{\mathrm{RM}}\right)$ cells $[5,6]$.

In this review, we will set this new finding in context to the existing knowledge of herpesvirus-specific $T_{\mathrm{RM}}$ cells, elaborate their distinctive features in the $\mathrm{SG}$, and discuss the implications for CMV immunity and vaccine strategies.

\section{Tissue-resident memory $\mathbf{T}$ cells control viral replication and reactivation at mucosal sites}

Classically, memory $T$ cells are divided into central memory $T$ cells $\left(T_{C M}\right)$ and effector memory $T$ cells $\left(T_{E M}\right)$ based on specific recirculation patterns. $T_{C M}$ cells circulate between lymphoid organs and blood and rapidly expand upon antigen re-encounter, while $T_{E M}$ cells survey inflamed peripheral sites and exert immediate effector functions. As a result of technical shortcomings, it was assumed that memory T cells found in peripheral tissues constantly and uniformly recirculate. Important revisions of this long-standing concept of circulatory immune surveillance were initiated by studies demonstrating the existence of non-recirculating $T_{R M}$ cells - a concept that is 
particularly well studied for $\mathrm{CD} 8^{+} \mathrm{T}$ cells. The tissue-resident nature of this population was functionally shown by the lack of recirculation via parabiotic surgery (the vascular conjoining of a naïve parabiont with an immune parabiont that harbours memory $T$ cells), tissue transplantation, and blockade of $T$ cell recirculation [7-10]. Sizeable proportions of $\mathrm{CD}^{+}$and $\mathrm{CD}^{+} \mathrm{T}_{\mathrm{RM}}$ cells express specific signature phenotypes, although recent studies indicate that these signatures are not sufficient for the identification of non-recirculating cells in tissues [11]. In the lung $C D 4^{+} T_{R M}$ cells co-express CD11a and CD69 [10], while CD8 ${ }^{+} T_{\text {RM }}$ cells co-express CD103 and CD69 and have been found in many tissues such as the skin, the brain, sensory ganglia, the intestinal mucosa, and secretory glands $[7,8,12-15]$. The inductive cues for $\mathrm{CD}^{+}$and $\mathrm{CD} 8^{+} \mathrm{T}_{\mathrm{RM}}$ generation and maintenance seem to be tissue- and context dependent. Antigen independent $\mathrm{CD} 8^{+} \mathrm{T}_{\mathrm{RM}}$ induction is supported in the gut, the skin, the female reproductive tract as well as in the SG $[5,6,15-17]$. In contrast, CD8 ${ }^{+}$ $\mathrm{T}_{\mathrm{RM}}$ formation in the brain occurs dependent of local antigen [12]. In case of CD4 ${ }^{+}$ $\mathrm{T}_{\mathrm{RM}}$ formation, cognate local antigen was dispensable in the lung after influenza virus infection [10] but was critical in the SG after MCMV infection $[5,6]$ and in the genital mucosa after HSV-2 infection [18].

$\mathrm{CD}^{+} \mathrm{T}_{\mathrm{RM}}$ in the lung and in mucosal vaginal tissue and $\mathrm{CD}^{+} \mathrm{T}_{\mathrm{RM}}$ cells in many tissues are long-lived and permanently positioned at peripheral sites that are prone to pathogenic invasion or reactivation, enabling them to respond most immediately to invading pathogens. In fact, the ability of circulating $T_{E M}$ cells to protect against peripheral infections is very limited $[9,16,19]$ and instead, $T_{R M}$ cells substantially contribute to pathogen elimination at these peripheral sites as demonstrated in numerous infection models including influenza and Mycobacterium tuberculosis 
infection of the lung or herpes simplex virus 1 (HSV-1) infection in skin and vaginal mucosa $[8,10,16]$.

\section{Herpesvirus infection generates protective $\mathrm{CD}^{+}$and $\mathrm{CD}^{+} \mathrm{T}_{\mathrm{RM}}$ cells at peripheral sites of viral reinfection}

The full benefit of $T_{R M}$ cells manifests in the defense against herpesviruses that maintain latent reservoirs in absence of inflammation and sporadically reactivate in epithelial and neuronal tissues. Under non-inflammatory conditions, these peripheral sites are highly restricted to circulating $T$ cells and the absence of $T_{R M}$ cells would render these tissues particularly vulnerable to viral reactivation and superinfection. The alpha-herpesviruses HSV-1 and HSV-2 establish latent reservoirs in innervating neurons of the skin and vaginal epithelium, respectively $[7,20]$. HSV-1-specific CD8 ${ }^{+}$ $\mathrm{T}_{\mathrm{RM}}$ cells that reside at these sites are able to rapidly detect HSV-1 and provide protective immunity in a manner that is superior to their circulating counterparts $[8,16,21,22]$. While the protection against local HSV-1 infection appears to be an exclusive function of $\mathrm{CD}^{+} \mathrm{T}_{\mathrm{RM}}$ cells, HSV-2 infection of the vaginal mucosa additionally establishes $\mathrm{CD} 4^{+} \mathrm{T}_{\mathrm{RM}}$ cells that provide protection against local HSV-2 infection $[18,23,24]$.

In humans, HCMV was described to preferentially establish latency in myeloid cells (reviewed in [25]) while in the murine model, the majority of the latent MCMV reservoir is found in non-hematopoietic cells and secretory glands including the SG [26]. During acute virus infection of the $\mathrm{SG}, \mathrm{CD} 4^{+} \mathrm{T}$ cells are required to establish viral latency because MCMV suppresses the function of effector $C D 8^{+} \mathrm{T}$ cells by highly efficient downregulation of MHC I molecules specifically in saliva producing epithelial cells $[3,4,27]$. Surprisingly, we recently demonstrated that while both $\mathrm{CD} 4^{+}$ 
and $\mathrm{CD}^{+} \mathrm{T}$ cells in the SG can adopt the phenotypic features of $\mathrm{T}_{\mathrm{RM}}$ cells (CD103 / CD69 co-expression for $\mathrm{CD}^{+} \mathrm{T}$ cells and CD11a / CD69 co-expression for $\mathrm{CD} 4^{+} \mathrm{T}$ cells) and are largely disconnected from the circulation (evidenced by absence of labelling by intravascularly administered antibodies and low level of equilibration between labelled cells within the SG and the vasculature), it is the $\mathrm{CD} 8^{+}$subset that protects against MCMV challenge infection in the SG [5], suggesting that these cells might also prevent viral reactivation from latency (Figure 1). Analysis of the cell types permissive for early MCMV infection in the SG indicated that MCMV targets largely non-epithelial cells in which MCMV fails to achieve complete MHC I downregulation, thereby providing a window of opportunity for readily positioned $\mathrm{CD} 8^{+} \mathrm{T}$ cells to detect viral antigen and control virus replication [5]. So far MCMV challenge experiments or CMV superinfection studies were mainly conducted using the subcutaneous route of reinfection, which is likely leading to a systemic viral challenge [28-31]. In challenge infection studies, systemic memory $C D 8^{+} \mathrm{T}$ cells were shown to afford protection against lethal challenge in immunocompromised murine hosts $[29,30]$ or to provide protection against systemic reactivation of HCMV in immunosuppressed organ transplant recipients [32-34]. However, in superinfection studies carried out in rhesus macaques, expression of CMV-encoded immune evasion genes was linked to the inability of $\mathrm{CMV}$-specific $\mathrm{CD}^{+} \mathrm{T}$ cell immunity in restricting subcutaneous CMV superinfection [28]. Our own data, however, indicate that MCMV-encoded immune evasion genes do not compromise the ability of SGresident $\mathrm{CD}^{+} \mathrm{T}_{\mathrm{RM}}$ cells in protecting against intraglandular challenge infection with MCMV [5].

The mechanisms by which $T_{R M}$ cells contain local infections are a field of active inquiry. $C D 8^{+} T_{R M}$ cells isolated from the brain, skin, and intestinal mucosa exert 
enhanced effector functions, such as rapid production of IFNy and target cell lysis $[9,12,35,36]$, demonstrating that $\mathrm{CD} 8^{+} \mathrm{T}_{\mathrm{RM}}$ cells are fully equipped to immediately control peripheral infection directly. Yet, the actions of $\mathrm{CD}^{+} \mathrm{T}_{\mathrm{RM}}$ cells stretch far beyond the classical antiviral effects of cytotoxic $T$ cells. By inducing local alterations of the tissue environment including the induction of antiviral and antibacterial gene expression, the activation of antigen-presenting cells and the recruitment of circulating immune cells, activated $\mathrm{CD} 8^{+} \mathrm{T}_{\mathrm{RM}}$ initiate a state of antimicrobial defence that can mediates protection against heterologous infections. Specifically, in a manner dependent on IFNy, TNF, and IL-2R, $\mathrm{CD}^{+} \mathrm{T}_{\mathrm{RM}}$ activation initiates the maturation of dendritic cells, the activation of NK cells, as well as the recruitment of memory $B$ and $T$ cells to an extent that can generate near-sterilising immunity against antigen-unrelated pathogens $[37,38]$. Moreover, instead of killing infected neurons and causing immunopathology, $\mathrm{CD} 8^{+} \mathrm{T}_{\mathrm{RM}}$ cells sustain HSV-1 latency by granzyme $\mathrm{B}$ mediated degradation of ICP4, an immediate early protein involved in viral replication [22].

\section{Phenotypic equivalents of $T_{R M}$ cells specific against herpesviruses exist in humans}

The discovery of $T_{R M}$ cells and their relevance in infection in the mouse model has prompted the search for equivalents of resident $T$ cell populations in humans. These efforts are highly limited by technical constraints, and mainly restrict the analysis to phenotypic characterizations of T cell populations.

Extensive analyses of the memory $\mathrm{T}$ cell composition in human tissues performed by Sathaliyawala et al. [39] revealed that memory $T$ cells exhibit tissue-specific compartmentalization throughout the human body, as well. Specifically, the vast 
majority of memory T cells in lymphoid and mucosal sites expresses CD69, whereas circulating memory $\mathrm{T}$ cells are CD69 negative. $\mathrm{CD} 8^{+}$memory $\mathrm{T}$ cells in mucosal sites furthermore specifically express CD103. Evidence suggests that herpesvirus-specific $\mathrm{CD}^{+} \mathrm{T}_{\mathrm{RM}}$ cells are also established in humans. For instance, $\mathrm{CD} 103^{+} \mathrm{CD} 8^{+} \mathrm{T}$ cells specific for Epstein Barr Virus (EBV) were found in human tonsils [40], and HSV-2 specific $\mathrm{CD}_{103^{+}} \mathrm{CD}^{+} \mathrm{T}$ cells were identified in human vaginal skin [41]. Turner et al. [42] reported that a significant proportion of $\mathrm{HCMV}$-specific $\mathrm{CD} 8^{+} \mathrm{T}$ cells expresses CD69 in the lung and spleen, indicating that CMV infection promotes the establishment of $T_{R M}$ populations in multiple tissues in humans. Yet, lung-resident memory CD8 ${ }^{+} \mathrm{T}$ cells specific for influenza virus and respiratory syncytial virus (RSV) predominantly express CD103, as opposed to HCMV-specific CD8 ${ }^{+}$memory $\mathrm{T}$ cells (reviewed in [43]), indicating that CD103 expression in the lung is a feature of memory $\mathrm{CD}^{+} \mathrm{T}$ cells specific for typical respiratory viruses. In line with this finding, we did not observe MCMV-specific CD103 expressing CD8 ${ }^{+} \mathrm{T}$ cells in murine lungs [5].

Importantly, in both mice and humans, memory $\mathrm{CD}^{+} \mathrm{T}$ cells outnumber memory $\mathrm{CD}^{+} \mathrm{T}$ cells in mucosal tissues [39,42], implying an evolutionary benefit from accommodating not only $\mathrm{CD} 8^{+}$but also $\mathrm{CD} 4^{+} \mathrm{T}$ cells in tissues. In mice, $\mathrm{CD} 4^{+} \mathrm{T}_{\mathrm{RM}}$ cells readily produce effector cytokines and were shown to protect naïve recipients in adoptive transfer experiments, from lethal influenza lung infection [10], suggesting that $C D 4^{+} T_{R M}$ cells are as efficient as $C D 8^{+} T_{R M}$ cells in their ability to mount rapid recall responses and control localized infection. In HSV-2 infection, CD4 ${ }^{+}$T cells play a key role in protection, while $C D 8^{+} T$ cells appear dispensable [44] and $C D 4^{+} T_{R M}$ cells were shown to efficiently protect against HSV-2 challenge. Whether $C D 4^{+} T_{R M}$ cells also provide protection against human herpesvirus infection has not yet been 
addressed. However, $\mathrm{CD} 4^{+} \mathrm{T}_{\mathrm{RM}}$ cells appear to exist in humans as well: Walrath et al. report tissue-retained $\mathrm{CD}^{+} \mathrm{T}$ cells in the lungs of tuberculosis patients [45]. Purwar et al. describe a lung-resident population of $\mathrm{CD}^{+} \mathrm{T}_{\mathrm{RM}}$ cells that are able to proliferate in response to stimulation with influenza antigen [46].

\section{Requirements for $\mathrm{T}_{\mathrm{RM}}$ induction are subset- and tissue-specific}

The protective benefit of both $\mathrm{CD}^{+}$as well as $\mathrm{CD}^{+} \mathrm{T}_{\mathrm{RM}}$ cell subsets in different models has encouraged efforts to specifically induce $T_{R M}$ cells in the context of vaccination or therapeutic approaches. To this end, it is crucial to define and understand the different requirements for $\mathrm{CD}^{+}$and $\mathrm{CD}^{+} \mathrm{T}_{\mathrm{RM}}$ generation and maintenance. In order to persist in a peripheral organ, $\mathrm{T}_{\mathrm{RM}}$ cells must resist signals that induce tissue egress. Lymphocytes are guided to efferent lymphatics by a chemotactic gradient of sphingosine-1-phospate (S1P), which is sensed by the S1P receptor 1 (S1PR1) and eventually enables tissue egress [47]. CD69 is expressed on the vast majority of $\mathrm{T}_{\mathrm{RM}}$ cells and antagonises the action of the S1PR1 by interfering with its cell surface expression, thus desensitising the $T_{\mathrm{RM}}$ cell towards S1P-mediated egress stimuli [48]. Another mechanism of $\mathrm{T}_{\mathrm{RM}}$ cell retention is integrin-mediated adhesion. The integrin CD103 tethers $T_{R M}$ cells to E-Cadherin, which is highly expressed on epithelial cells [49]. In consequence, CD103-expressing CD8 ${ }^{+} \mathrm{T}_{\mathrm{RM}}$ cells preferentially co-localize with epithelial structures [21]. Tissue retention of CD103 deficient $\mathrm{CD}^{+} \mathrm{T}$ cells is strikingly impaired in a variety of peripheral tissues $[12,17,50]$. However, not all $T_{\mathrm{RM}}$ cells rely on CD103 for their retention as indicated by the existence of CD103 negative $\mathrm{CD}^{+} \mathrm{T}_{\mathrm{RM}}$ cells $[11,12]$. Moreover, CD103 expression in $\mathrm{CD}^{+} \mathrm{T}_{\mathrm{RM}}$ cells is largely absent [51]. Apart from CD103, the integrin 
VLA-1 interacts with collagen and laminin and its expression was found in CD8 ${ }^{+} T_{R M}$ cells in the brain, gut, lung, and skin, as well as on $\mathrm{CD}^{+} \mathrm{T}_{\mathrm{RM}}$ cells $[8,50-53]$.

The requirements for $T$ cells to take up residence and activate the required pathways for their retention in tissues are yet to be precisely defined. The impact of local cognate antigenic stimulation on the maintenance of $\mathrm{CD}^{+}$as well as $\mathrm{CD} 4^{+} \mathrm{T}_{\mathrm{RM}}$ cells appears to depend on the tissue of residence. In a broad variety of peripheral tissues including gut, lung, and skin, ongoing antigenic stimulation is not required to induce CD103 expression $[7,16]$. However, CD103 expression on $\mathrm{CD}^{+} \mathrm{T}$ cells in neuronal tissue appears to be strictly dependent on cognate antigen in a model of VSV brain infection [12,17]. Teijaro et al. found that influenza-specific, lung-retained $C D 4^{+} T_{R M}$ cells acquired $\mathrm{T}_{\mathrm{RM}}$ properties in a manner that is independent of antigen [10]. Our recent data indicate that SG-resident $C D 4^{+} T_{R M}$ cells rely on the presence of local antigen [5]. Taken together, these data clearly indicate that the tissue of residence decides upon the antigen dependence of $\mathrm{T}_{\mathrm{RM}}$ formation and lodgement. Whether tissue-inherent factors outweigh subset-specific demands is not sufficiently elucidated, as studies that directly compare $\mathrm{CD} 8^{+}$and $\mathrm{CD} 4^{+} \mathrm{T}_{\mathrm{RM}}$ formation within the same organ are scarce. Our data suggest that subset-specific demands outweigh tissue-intrinsic factors as $C D 4^{+} T_{R M}$ generation in the $S G$ relied on local cognate antigen, while $\mathrm{CD}^{+} \mathrm{T}_{\mathrm{RM}}$ generation was antigen-independent (Figure 1).

\section{Implications for CMV-based vaccines}

The protective benefit of both $\mathrm{CD} 4^{+}$as well as $\mathrm{CD} 8^{+} \mathrm{T}_{\mathrm{RM}}$ cell subsets in different infection models has encouraged efforts to induce $T_{R M}$ cells in the context of vaccination approaches. 
CMV based vectors hold considerable potential in T cell vaccine development for several reasons: The asymptomatic, yet persistent and sporadically reactivating nature of CMV infection leads to the induction and maintenance of strong effector $\mathrm{T}$ cell responses, even if profoundly attenuated variants of CMV are used [54]. Furthermore, CMVs ability to superinfect allows for vaccination of CMV-immune individuals. These promising aspects were confirmed in rhesus macaques that were injected with recombinant rhesus CMV (RhCMV) expressing genes of simian immunodeficiency virus (SIV). This vaccine approach generated $C D 8^{+} T_{E M}$ cells which were able to restrict SIV replication at the site of infection and was superior to previously tested adenoviral vaccines that mainly induced $\mathrm{T}_{\mathrm{CM}}$ responses $[55,56]$. The discovery that CMV infection is a potent inducer of both mucosa-resident CD4 ${ }^{+}$ and $C D 8^{+} T_{R M}$ cells extends the scope of CMV-based vaccines even further, holding promising implications for vaccine strategies against pathogens that invade mucosae. Moreover, the efficient induction of a continuously growing population of inflationary memory CD8 ${ }^{+} \mathrm{T}$ cells induced specifically by CMV $[57,58]$ (Figure 1 ) could be highly beneficial for the maintenance of large $C D 8^{+} T_{R M}$ populations. We have evidence that these inflationary cells, which are fueled by re-activated $\mathrm{CD} 8^{+}$memory $\mathrm{T}$ cells from LNs [26] and vascular sources [59] can provide low-level resupply of the CD8 ${ }^{+} T_{R M}$ population in the SG $[5,6]$ (Figure 1). This resupply might even render CD8 ${ }^{+} T_{R M}$ cells independent of factors that are required for the maintenance of $C D 8^{+} T_{R M}$ cells in other organs, i.e. the integrin $C D 103$, which is associated with $T_{R M}$ cell retention in many other tissues $[12,17,50]$.

Whether functional $C D 4^{+} T_{R M}$ cells can be generated by the same measures as $C D 8^{+}$ $T_{R M}$ cells still requires further investigation. Insightful data were obtained from intravaginal HSV-2 infection, which leads to the lodgement of both $\mathrm{CD} 8^{+}$and $\mathrm{CD} 4^{+}$ 
$\mathrm{T}_{\mathrm{RM}}$ populations. As opposed to intravaginal HSV-2 infection, a conventional parenteral vaccination strategy elicited systemic $\mathrm{CD} 8^{+}$and $\mathrm{CD} 4^{+} \mathrm{T}$ cell responses ("prime") which could be attracted to the vaginal mucosal tissue by topical application of chemokines (CXCL9/10) ("pull"). Interestingly, despite the initial recruitment of both $\mathrm{CD}^{+}$and $\mathrm{CD} 8^{+} \mathrm{T}$ cells by the chemokine "pull", formation of a long-lived resident population was restricted to $\mathrm{CD}^{+} \mathrm{T}$ cells [18]. These results indicate that $\mathrm{CD} 4^{+} \mathrm{T}$ cells require additional factors locally provided by HSV-2 infection for long term maintenance. Our recent findings indicate that $\mathrm{CD}^{+} \mathrm{T}_{\mathrm{RM}}$ formation is strictly dependent on the local presence of cognate antigen, thus corroborating the notion that that these two subsets demand different requirements from the same organ for $\mathrm{T}_{\mathrm{RM}}$ generation [5]. These new insights should be taken into consideration for the route and site of administration of vaccines that aim to induce functional $C D 4^{+} T_{R M}$ populations.

\section{Conclusions}

$\mathrm{T}_{\mathrm{RM}}$ cells act as on-site guards of peripheral immunity that contain localized reinfection of barrier tissues such as mucosae and skin. Their specific strength lies within their ability to immediately purge infection when circulating cells are lagging behind. In case of CMV infection, this benefit is highlighted by the ability of $C D 8^{+} \mathrm{T}$ cells to contain CMV infection in the SG when they are readily positioned before CMVs immune evasion program achieves its maximal impact.

The $T_{R M}$ concept appears universally favourable, given the ubiquity of $T_{R M}$ cells in various tissues. Yet, $\mathrm{CD} 4^{+}$and $\mathrm{CD} 8^{+} \mathrm{T}_{\mathrm{RM}}$ cells require differential inductive cues from the same tissues. Understanding how $\mathrm{T}_{\mathrm{RM}}$ cells are recruited and maintained is 
critically required to open promising opportunities for therapeutic and prophylactic intervention strategies that utilize the unique benefits of $T_{R M}$ subsets.

\section{Acknowledgements}

We are grateful to the members of the Oxenius group for helpful discussions and critical reading of the manuscript. We would like to apologize that we could not comprehensively acknowledge the literature in this filed due to limitations in the number of references. This work was supported by the ETH and the Swiss National Science Foundation (Grant No. 310030-146140 to AO). 


\section{References}

[1] Torti $\mathrm{N}$, Oxenius A: T cell memory in the context of persistent herpes viral infections. Viruses 2012, 4:1116-1143.

[2] Lucin P, Pavic I, Polic B, Jonjic S, Koszinowski UH: Gamma interferondependent clearance of cytomegalovirus infection in salivary glands. $J$ Virol 1992, 66:1977-1984.

[3] Walton SM, Mandaric S, Torti N, Zimmermann A, Hengel H, Oxenius A: Absence of cross-presenting cells in the salivary gland and viral immune evasion confine cytomegalovirus immune control to effector CD4 T cells. PLOS Pathog 2011, 7:e1002214.

[4] Lu X, Pinto AK, Kelly AM, Cho KS, Hill AB: Murine cytomegalovirus interference with antigen presentation contributes to the inability of CD8 T cells to control virus in the salivary gland. J Virol 2006, 80:4200-4202.

** [5] Thom JT, Weber TC, Walton SM, Torti N, Oxenius A: The Salivary Gland Acts as a Sink for Tissue-Resident Memory CD8(+) T Cells, Facilitating Protection from Local Cytomegalovirus Infection. Cell Rep 2015, 13:1125-1136.

First in vivo characterization of the phenotypical and functional properties of tissueresident MCMV-specific $\mathrm{CD} 4^{+}$and $\mathrm{CD} 8^{+} \mathrm{T}$ cells in the salivary gland (SG) including the delineation of the inductive cues for their establishment. SG-resident CD8 ${ }^{+} T$ cells were shown to confer protection against intraglandular MCMV challenge owing to recognition of MCMV infected target cells prior to full MCMV-mediated MHC class I downregulation.

** [6] Smith CJ, Caldeira-Dantas S, Turula H, Snyder CM: Murine CMV Infection Induces the Continuous Production of Mucosal Resident T Cells. Cell Rep 2015, 13:1137-1148. 
Frist demonstration of a dynamic regulation of $C D 8^{+} T_{R M}$ populations in the $S G$ after MCMV infection: after initial establishment of a pronounced $C D 8^{+} \mathrm{T}_{\mathrm{RM}}$ population in the SG, low numbers of new $C D 8^{+} T_{R M}$ could be recuited from the circulating pool of MCMV-specific $\mathrm{CD}^{+} \mathrm{T}$ cells throughout infection, resulting in comparable immunodominance within circulating and $\mathrm{T}_{\mathrm{RM}} \mathrm{CD} 8^{+} \mathrm{T}$ cell populations over time.

[7] Klonowski KD, Williams KJ, Marzo AL, Blair DA, Lingenheld EG, Lefrancois L: Dynamics of blood-borne CD8 memory T cell migration in vivo. Immunity 2004, 20:551-562.

[8] Gebhardt T, Wakim LM, Eidsmo L, Reading PC, Heath WR, Carbone FR: Memory $\mathbf{T}$ cells in nonlymphoid tissue that provide enhanced local immunity during infection with herpes simplex virus. Nat Immunol 2009, 10:524-530.

[9] Jiang X, Clark RA, Liu L, Wagers AJ, Fuhlbrigge RC, Kupper TS: Skin infection generates non-migratory memory CD8+ T(RM) cells providing global skin immunity. Nature 2012, 483:227-231.

[10] Teijaro JR, Turner D, Pham Q, Wherry EJ, Lefrancois L, Farber DL: Cutting edge: Tissue-retentive lung memory CD4 T cells mediate optimal protection to respiratory virus infection. $J$ Immunol 2011, 187:5510-5514.

** [11] Steinert EM, Schenkel JM, Fraser KA, Beura LK, Manlove LS, Igyarto BZ, Southern PJ, Masopust D: Quantifying Memory CD8 T Cells Reveals Regionalization of Immunosurveillance. Cell 2015, 161:737-749. Milestone report about present shortcomings in quantifiying $\mathrm{T}$ cells in peripheral tissues, implicating the use of quantitative immunofluorescence microscopy and parabiosis experiments for accurate enumartion of tissue-resident memory $\mathrm{CD} 8^{+} \mathrm{T}$ cells as conventional methods for lymphocyte isolation fall short in quantitative recovery of tissue-resdient $T$ cells. Using quantitative immunofluorescence microscopy and parabiosis experiments T cells resident within non-lymphoid tissues 
were found to vastly outnumber recirculating cells, further emphasizing their role in tissue surveillance.

[12] Wakim LM, Woodward-Davis A, Bevan MJ: Memory T cells persisting within the brain after local infection show functional adaptations to their tissue of residence. Proc Natl Acad Sci U S A 2010, 107:17872-17879.

[13] Schon MP, Arya A, Murphy EA, Adams CM, Strauch UG, Agace WW, Marsal J, Donohue JP, Her $\mathrm{H}$, Beier DR, et al.: Mucosal $\mathbf{T}$ lymphocyte numbers are selectively reduced in integrin alpha E (CD103)-deficient mice. J Immunol 1999, 162:6641-6649.

[14] Kim SK, Reed DS, Heath WR, Carbone F, Lefrancois L: Activation and migration of CD8 T cells in the intestinal mucosa. J Immunol 1997, 159:42954306 .

[15] Hofmann M, Pircher H: E-cadherin promotes accumulation of a unique memory CD8 T-cell population in murine salivary glands. Proc Natl Acad Sci U S A 2011, 108:16741-16746.

[16] Mackay LK, Stock AT, Ma JZ, Jones CM, Kent SJ, Mueller SN, Heath WR, Carbone FR, Gebhardt T: Long-lived epithelial immunity by tissue-resident memory T (TRM) cells in the absence of persisting local antigen presentation. Proc Natl Acad Sci U S A 2012, 109:7037-7042.

[17] Casey KA, Fraser KA, Schenkel JM, Moran A, Abt MC, Beura LK, Lucas PJ, Artis D, Wherry EJ, Hogquist K, et al.: Antigen-independent differentiation and maintenance of effector-like resident memory $\mathrm{T}$ cells in tissues. $J$ Immunol 2012, 188:4866-4875.

[18] Shin $\mathrm{H}$, Iwasaki A: A vaccine strategy that protects against genital herpes by establishing local memory T cells. Nature 2012, 491:463-467. 
[19] Bachmann MF, Wolint P, Schwarz K, Oxenius A: Recall proliferation potential of memory CD8+ T cells and antiviral protection. J Immunol 2005, 175:46774685.

[20] Gebhardt T, Whitney PG, Zaid A, Mackay LK, Brooks AG, Heath WR, Carbone FR, Mueller SN: Different patterns of peripheral migration by memory CD4+ and CD8+ T cells. Nature 2011, 477:216-219.

[21] Ariotti S, Beltman JB, Chodaczek G, Hoekstra ME, van Beek AE, GomezEerland R, Ritsma L, van Rheenen J, Maree AF, Zal T, et al.: Tissue-resident memory CD8+ $T$ cells continuously patrol skin epithelia to quickly recognize local antigen. Proc Natl Acad Sci U S A 2012, 109:19739-19744.

[22] Knickelbein JE, Khanna KM, Yee MB, Baty CJ, Kinchington PR, Hendricks RL: Noncytotoxic lytic granule-mediated CD8+ T cell inhibition of HSV-1 reactivation from neuronal latency. Science 2008, 322:268-271.

* [23] lijima N, Iwasaki A: T cell memory. A local macrophage chemokine network sustains protective tissue-resident memory CD4 T cells. Science 2014, 346:9398.

Local protection against HSV-2 challenge was mediated by pre-existing CD4 ${ }^{+} T_{\mathrm{RM}}$ in the genital mucosa. Importantly, local macrophages were essential in retaining $\mathrm{CD}^{+}$ $\mathrm{T}_{\mathrm{RM}}$ in the vaginal mucosa by providing a local CCL5 that supported formation and maintenance of lymphocyte clusters containing HSV-2-specififc CD4 ${ }^{+} \mathrm{T}_{\mathrm{RM}}$. These results emphasize the stablishment of $T_{R M}$ cells in the context of vaccines against sexually transmitted viral diseases.

* [24] Zhu J, Peng T, Johnston C, Phasouk K, Kask AS, Klock A, Jin L, Diem K, Koelle DM, Wald A, et al.: Immune surveillance by CD8alphaalpha+ skin-resident T cells in human herpes virus infection. Nature 2013, 497:494-497. 
One of the first studies associating HSV-2 control in human skin with the presence of long-term persisting, skin-resident antivirally active oligoclonal CD8 $\alpha \alpha^{+} T$ cells. Those cells lack chemokine receptor required for tissue emigration. Importantly, rapid HSV2 control was associated with focal abundance of $\operatorname{CD} 8 \alpha \alpha^{+} T$ cells, suggesting a critical role in tissue surveillance and rapid containment of HSV-2 reactivation in human skin.

[25] Sinclair J: Human cytomegalovirus: Latency and reactivation in the myeloid lineage. J Clin Virol 2008, 41:180-185.

[26] Torti N, Walton SM, Brocker T, Rulicke T, Oxenius A: Non-hematopoietic cells in lymph nodes drive memory CD8 $T$ cell inflation during murine cytomegalovirus infection. PLOS Pathog 2011, 7:e1002313.

[27] Jonjic S, Mutter W, Weiland F, Reddehase MJ, Koszinowski UH: Site-restricted persistent cytomegalovirus infection after selective long-term depletion of CD4+ T lymphocytes. J Exp Med 1989, 169:1199-1212.

[28] Hansen SG, Powers CJ, Richards R, Ventura AB, Ford JC, Siess D, Axthelm MK, Nelson JA, Jarvis MA, Picker LJ, et al.: Evasion of CD8+ T cells is critical for superinfection by cytomegalovirus. Science 2010, 328:102-106. [29] Holtappels R, Simon CO, Munks MW, Thomas D, Deegen P, Kuhnapfel B, Daubner T, Emde SF, Podlech J, Grzimek NK, et al.: Subdominant CD8 T-cell epitopes account for protection against cytomegalovirus independent of immunodomination. J Virol 2008, 82:5781-5796.

[30] Bohm V, Podlech J, Thomas D, Deegen P, Pahl-Seibert MF, Lemmermann NA, Grzimek NK, Oehrlein-Karpi SA, Reddehase MJ, Holtappels R: Epitope-specific in vivo protection against cytomegalovirus disease by CD8 T cells in the murine model of preemptive immunotherapy. Med Microbiol Immunol 2008, 197:135-144. 
[31] Reddehase MJ, Mutter W, Munch K, Buhring HJ, Koszinowski UH: CD8-positive T lymphocytes specific for murine cytomegalovirus immediate-early antigens mediate protective immunity. J Virol 1987, 61:3102-3108.

[32] Nauerth M, Weissbrich B, Knall R, Franz T, Dossinger G, Bet J, Paszkiewicz PJ, Pfeifer L, Bunse M, Uckert W, et al.: TCR-ligand koff rate correlates with the protective capacity of antigen-specific CD8+ $\mathrm{T}$ cells for adoptive transfer. Sci Transl Med 2013, 5:192ra187.

[33] Scheinberg P, Melenhorst JJ, Brenchley JM, Hill BJ, Hensel NF, Chattopadhyay PK, Roederer M, Picker LJ, Price DA, Barrett AJ, et al.: The transfer of adaptive immunity to CMV during hematopoietic stem cell transplantation is dependent on the specificity and phenotype of CMV-specific T cells in the donor. Blood 2009, 114:5071-5080.

[34] Bunde T, Kirchner A, Hoffmeister B, Habedank D, Hetzer R, Cherepnev G, Proesch S, Reinke P, Volk HD, Lehmkuhl H, et al.: Protection from cytomegalovirus after transplantation is correlated with immediate early 1specific CD8 T cells. J Exp Med 2005, 201:1031-1036.

[35] Masopust D, Vezys V, Marzo AL, Lefrancois L: Preferential localization of effector memory cells in nonlymphoid tissue. Science 2001, 291:2413-2417. [36] Hawke S, Stevenson PG, Freeman S, Bangham CR: Long-term persistence of activated cytotoxic T lymphocytes after viral infection of the central nervous system. J Exp Med 1998, 187:1575-1582.

** [37] Ariotti S, Hogenbirk MA, Dijkgraaf FE, Visser LL, Hoekstra ME, Song JY, Jacobs $\mathrm{H}$, Haanen JB, Schumacher TN: T cell memory. Skin-resident memory CD8(+) T cells trigger a state of tissue-wide pathogen alert. Science 2014, 346:101-105. 
One of the first reports identifying the protective mechanism of $C D 8^{+} T_{R M}$ also in case

of heterologous challenge infections. Activated $\mathrm{CD}^{+} \mathrm{T}_{\mathrm{RM}}$ were found to rapidly induce transcription of various antiviral and antibacterial genes via secretion of IFN $\gamma$, including chemokines and cytokines involved in innate immune cell activation and recruitment. This local induction of a broad antiviral a state provides a mechanistic explanation for the protection against antigenically heterologous virus challenge.

* [38] Schenkel JM, Fraser KA, Masopust D: Cutting edge: resident memory CD8 T cells occupy frontline niches in secondary lymphoid organs. J Immunol 2014, 192:2961-2964.

First report identifying a population of $\mathrm{CD} 8^{+} \mathrm{T}_{\mathrm{RM}}$ cells in secondary lymphoid organs: A proportion of virus-specific memory $C D 8^{+} T$ cells show phenotypic features of $T_{R M}$ cells, are disconnnected from the circulation and localize at entry points of secondary lymphoid organs (splenic marginal zone, red pulp, and lymph node sinuses), implying a role in surveilling entry ports of secondary lymphoid organs.

** [39] Sathaliyawala T, Kubota M, Yudanin N, Turner D, Camp P, Thome JJ, Bickham $K L$, Lerner $H$, Goldstein $M$, Sykes $M$, et al.: Distribution and compartmentalization of human circulating and tissue-resident memory $\mathrm{T}$ cell subsets. Immunity 2013, 38:187-197.

First comprehensive analysis of human T cell subset distribution in circulation and tissues from deceased organ donors. This unique analysis revealed that effector memory $\mathrm{CD} 4^{+}$and $\mathrm{CD} 8^{+} \mathrm{T}$ cells were abundant in mucosal tissues whereas central memory subsets and naïve $T$ cells were localized to lymphoid tissues. Interestingly, in non-lymphoid tissues - as opposed to the circulation - memory $T$ cells expressed CD69, indicative for $T_{R M}$ cells.

[40] Hislop AD, Kuo M, Drake-Lee AB, Akbar AN, Bergler W, Hammerschmitt N, Khan N, Palendira U, Leese AM, Timms JM, et al.: Tonsillar homing of Epstein- 
Barr virus-specific CD8+ T cells and the virus-host balance. J Clin Invest 2005, 115:2546-2555.

[41] Zhu J, Hladik F, Woodward A, Klock A, Peng T, Johnston C, Remington M, Magaret A, Koelle DM, Wald A, et al.: Persistence of HIV-1 receptor-positive cells after HSV-2 reactivation is a potential mechanism for increased HIV-1 acquisition. Nat Med 2009, 15:886-892.

[42] Turner DL, Bickham KL, Thome JJ, Kim CY, D'Ovidio F, Wherry EJ, Farber DL: Lung niches for the generation and maintenance of tissue-resident memory $\mathbf{T}$ cells. Mucosal Immunol 2014, 7:501-510.

[43] van Aalderen MC, Remmerswaal EB, ten Berge IJ, van Lier RA: Blood and beyond: properties of circulating and tissue-resident human virus-specific alphabeta CD8(+) T cells. Eur J Immunol 2014, 44:934-944.

[44] Eriksson K, Bellner L, Gorander S, Lowhagen GB, Tunback P, Rydberg K, Liljeqvist JA: CD4(+) T-cell responses to herpes simplex virus type 2 (HSV-2) glycoprotein $\mathrm{G}$ are type specific and differ in symptomatic and asymptomatic HSV-2-infected individuals. J Gen Virol 2004, 85:2139-2147.

[45] Walrath J, Zukowski L, Krywiak A, Silver RF: Resident Th1-like effector memory cells in pulmonary recall responses to Mycobacterium tuberculosis. Am J Respir Cell Mol Biol 2005, 33:48-55.

[46] Purwar R, Campbell J, Murphy G, Richards WG, Clark RA, Kupper TS: Resident memory $T$ cells ( $T(R M))$ are abundant in human lung: diversity, function, and antigen specificity. PLOS One 2011, 6:e16245.

[47] Matloubian M, Lo CG, Cinamon G, Lesneski MJ, Xu Y, Brinkmann V, Allende ML, Proia RL, Cyster JG: Lymphocyte egress from thymus and peripheral lymphoid organs is dependent on S1P receptor 1. Nature 2004, 427:355-360. 
[48] Shiow LR, Rosen DB, Brdickova N, Xu Y, An J, Lanier LL, Cyster JG, Matloubian M: CD69 acts downstream of interferon-alpha/beta to inhibit S1P1 and lymphocyte egress from lymphoid organs. Nature 2006, 440:540-544.

[49] Cepek KL, Shaw SK, Parker CM, Russell GJ, Morrow JS, Rimm DL, Brenner MB: Adhesion between epithelial cells and T lymphocytes mediated by $E$ cadherin and the alpha E beta 7 integrin. Nature 1994, 372:190-193.

[50] Mackay LK, Rahimpour A, Ma JZ, Collins N, Stock AT, Hafon ML, Vega-Ramos J, Lauzurica P, Mueller SN, Stefanovic T, et al.: The developmental pathway for CD103(+)CD8+ tissue-resident memory T cells of skin. Nat Immunol 2013, 14:1294-1301.

[51] Chapman TJ, Topham DJ: Identification of a unique population of tissuememory CD4+ $T$ cells in the airways after influenza infection that is dependent on the integrin VLA-1. J Immunol 2010, 184:3841-3849.

[52] Wakim LM, Woodward-Davis A, Liu R, Hu Y, Villadangos J, Smyth G, Bevan MJ: The molecular signature of tissue resident memory CD8 T cells isolated from the brain. $J$ Immunol 2012, 189:3462-3471.

[53] Ray SJ, Franki SN, Pierce RH, Dimitrova S, Koteliansky V, Sprague AG, Doherty PC, de Fougerolles AR, Topham DJ: The collagen binding alpha1beta1 integrin VLA-1 regulates CD8 T cell-mediated immune protection against heterologous influenza infection. Immunity 2004, 20:167-179.

[54] Slavuljica I, Busche A, Babic M, Mitrovic M, Gasparovic I, Cekinovic D, Markova Car E, Pernjak Pugel E, Cikovic A, Lisnic VJ, et al.: Recombinant mouse cytomegalovirus expressing a ligand for the NKG2D receptor is attenuated and has improved vaccine properties. J Clin Invest 2010, 120:4532-4545.

[55] Hansen SG, Vieville C, Whizin N, Coyne-Johnson L, Siess DC, Drummond DD, Legasse AW, Axthelm MK, Oswald K, Trubey CM, et al.: Effector memory T cell 
responses are associated with protection of rhesus monkeys from mucosal simian immunodeficiency virus challenge. Nat Med 2009, 15:293-299.

[56] Hansen SG, Ford JC, Lewis MS, Ventura AB, Hughes CM, Coyne-Johnson L, Whizin N, Oswald K, Shoemaker R, Swanson T, et al.: Profound early control of highly pathogenic SIV by an effector memory T-cell vaccine. Nature 2011, 473:523-527.

[57] Karrer U, Sierro S, Wagner M, Oxenius A, Hengel H, Koszinowski UH, Phillips RE, Klenerman P: Memory inflation: continuous accumulation of antiviral CD8+ T cells over time. J Immunol 2003, 170:2022-2029.

[58] Munks MW, Cho KS, Pinto AK, Sierro S, Klenerman P, Hill AB: Four distinct patterns of memory CD8 $\mathrm{T}$ cell responses to chronic murine cytomegalovirus infection. J Immunol 2006, 177:450-458.

[59] Smith CJ, Turula H, Snyder CM: Systemic hematogenous maintenance of memory inflation by MCMV infection. PLoS Pathog 2014, 10:e1004233. 


\section{Figure legend}

Figure 1 MCMV-specific T cell responses

Dynamics of systemic MCMV-specific CD4 $4^{+}$and $C D 8^{+} T$ cell responses (left). MCMVspecific $\mathrm{CD}^{+} \mathrm{T}$ cell responses (red line) and s subset of MCMV-specific CD8 ${ }^{+} \mathrm{T}$ cell responses (striped blue line) follow a conventional expansion - contraction - memory pattern. In contrast, a subset of MCMV-specific $\mathrm{CD}^{+} \mathrm{T}$ cell responses (blue line) continue to expand and establish high level of a stable population of activated $\mathrm{T}_{\mathrm{EM}}$ cells (termed memory inflation).

In particular in the salivary gland a majority of MCMV-specific CD4 $4^{+}$and $C D 8^{+} T$ cells adopts a $T_{R M}$ phenotype (middle). The pie charts indicate the relative proportion of MCMV-specific CD8 ${ }^{+}$and CD4 ${ }^{+}$T cells that co-express CD103 and CD69 (for CD8 ${ }^{+} \mathrm{T}$ cells) or CD11a and CD69 (for CD4 ${ }^{+}$T cells).

Factors that promote $C D 4^{+}$and $C D 8^{+} T_{R M}$ induction in the salivary gland and protective function of MCMV-specific $T_{R M}$ in the salivary gland (right). Induction of a $\mathrm{T}_{\mathrm{RM}}$ phenotype relies on TGF $\beta$ signaling for $\mathrm{CD}^{+} \mathrm{T}$ cells and is independent of local antigen. In contrast, induction of the $\mathrm{T}_{\mathrm{RM}}$ phenotype in $\mathrm{CD} 4^{+} \mathrm{T}$ cells depends on local antigen but is independent of TGF $\beta$. MCMV-specific $C D 8^{+} \mathrm{T}_{\mathrm{RM}}$ cells can continuously be recruited from the pool of circulating cells to the salivary gland - also during viral latency. MCMV-specific CD8 ${ }^{+} \mathrm{T}_{\mathrm{RM}}$ cells can protect against a local challenge infection with MCMV. 
Fingubecific T cell response patterns

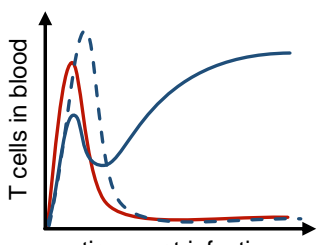

time post infection

— inflationary $\mathrm{CD}^{+}$

- - - conventional CD8 ${ }^{+}$

C CD4 ${ }^{+} \mathrm{T}$ cells
$\mathrm{T}_{\mathrm{RM}}$ phenotype*

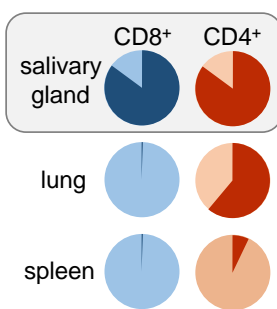

* ${ }^{*} \mathrm{CD} 103{ }^{+} \mathrm{CD} 69^{+}$

* ${ }^{*} \mathrm{CD} 11 \mathrm{a}^{+} \mathrm{CD}{ }^{+}$
MCMV-specific $T_{R M}$ cells in the salivary gland

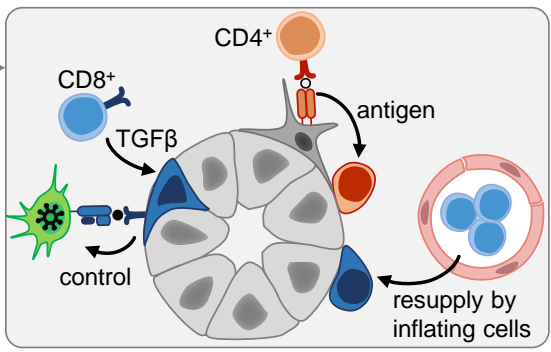

P MHC I $\prod_{\text {M }}$ MHC II ${ }_{\text {receptor }}^{T}$ cell $\bigcirc T_{R M}$ cell 